\title{
Paper
}

\section{Oxygen Release Property of Ceria/Alumina Composite Powder in Reducing Atmosphere at Low Temperatures}

\author{
Masatomo HATTORI, Masaaki HANEDA and Masakuni OZAWA \\ Advanced Ceramics Research Center, Nagoya Institute of Technology, Asahigaoka, Tajimi 507-0071, Japan.
}

Received September 8, 2012

\begin{abstract}
Oxygen release property of ceria $\left(\mathrm{CeO}_{2}\right)$ in ceria/alumina composite powder by hydrogen was examined by the temperature-programmed reduction technique below the temperature of $600{ }^{\circ} \mathrm{C}$. The results suggested the strong interaction and the structural relaxation at the interface of $\mathrm{CeO}_{2}$ and $\mathrm{Al}_{2} \mathrm{O}_{3}$ after the redox treatment at low temperatures. The activation energy of oxygen release by hydrogen was determined as $85 \pm 15 \mathrm{~kJ} / \mathrm{mol}$ for the interface of $\mathrm{CeO}_{2} / \mathrm{Al}_{2} \mathrm{O}_{3}$. Furthermore it increased to $194 \pm 25 \mathrm{~kJ} / \mathrm{mol}$ after the redox treatment, because oxygen was stabilized at the interface between alumina and ceria. This means that the interface is stabilized to produce the relaxed structure of interface in which oxygen is also stabilized.
\end{abstract}

KEY WORDS

ceria, alumina, interface, oxygen release, oxygen storage capacity

\section{Introduction}

Cerium oxide $\left(\mathrm{CeO}_{\mathrm{x}}\right)$ is useful as a textural and structural promoter of ceramics as well as an additive for stabilization of alumina catalytic support ${ }^{1-4)}$. The crystalline oxides of cerium have two polymorphs, $\mathrm{CeO}_{2}$ and $\mathrm{Ce}_{2} \mathrm{O}_{3}$, and also a series of $\mathrm{CeO}_{2-x}$ with oxygen defects are available as catalyst and oxygen getter in redox process ${ }^{5,6)}$. The composite material between $\mathrm{CeO}_{2}$ and $\mathrm{Al}_{2} \mathrm{O}_{3}$ is a typical raw composition and one of important catalytic materials for the removal of $\mathrm{CO}$, hydrocarbons and nitrogen oxides from gasoline engine exhaust gas. The ceria also is required for controlling oxygen content by oxygen storage capacity (OSC) for achieving the precise oxygen pressure in reaction conditions ${ }^{1,3,4,7,8)}$. The OSC has been known to be related to the redox and nonstoichiometry of $\mathrm{CeO}_{2}$-related compounds, and modified by the addition of $\mathrm{ZrO}_{2}$. In the system of $\mathrm{CeO}_{2}-\mathrm{Al}_{2} \mathrm{O}_{3}, \mathrm{CeO}_{2}$ stabilize the metastable phase of alumina and inhibit the sintering at elevated temperature $^{9-11)}$. Also, the solid state reaction between $\mathrm{CeO}_{2}$ and $\mathrm{Al}_{2} \mathrm{O}_{3}$ forms crystalline $\mathrm{CeAlO}_{3}$ at as higher temperature as $900{ }^{\circ} \mathrm{C}$ if it is treated under reducing condition including hydrogen-containing gas ${ }^{11,12)}$. While recently, it was reported that in the low temperature region ceria has been stabilized as nanoparticles on alumina, and induced better oxygen evolution properties ${ }^{13)} \cdot \mathrm{CeO}_{2}$ nanoparticle is potentially useful as active catalyst and additive agents for sintering at low temperatures, so the interaction between nanoparticles and its substrate or support at the interface will become important factor. In this work, by using the hydrogen temperature-programmed reduction technique, we have indicated the existence of strong interaction at the interface between $\mathrm{CeO}_{2}$ and $\mathrm{Al}_{2} \mathrm{O}_{3}$ particles under reducing atmosphere below $600^{\circ} \mathrm{C}$. We have found unordinary phenomena of ceria particles mixed with alumina, in which the redox of $\mathrm{CeO}_{2} / \mathrm{Al}_{2} \mathrm{O}_{3}$ is possible in as low temperature region as $600^{\circ} \mathrm{C}$. This is new findings about ceria additive in alumina which will potentially be useful in the case of use of ceria as agent in redox heat condition as well as heterogeneous catalytic reaction.

\section{Experimental}

The composite powder between $\mathrm{CeO}_{2}$ and $\mathrm{Al}_{2} \mathrm{O}_{3}$ $\left(\mathrm{CeO}_{2}: \mathrm{Al}_{2} \mathrm{O}_{3}=3: 10\right.$ in molar ratio) was prepared by the impregnation-mixing process of alumina powder (Sumitomo chemical, AKPG015, surface area $135 \mathrm{~m}^{2} / \mathrm{g}$, Japan) into an aqueous solution of $\mathrm{Ce}\left(\mathrm{NO}_{3}\right)_{3} 6 \mathrm{H}_{2} \mathrm{O}$ (Wako, $99.9 \%$ purity, Japan). The mixed slurry was dried overnight at $110^{\circ} \mathrm{C}$, and heated at $500^{\circ} \mathrm{C}$ for $3 \mathrm{~h}$ in air, and then was heated at $600{ }^{\circ} \mathrm{C}$ for $3 \mathrm{~h}$ in air. The crystalline phase in powders was identified by an X-ray powder diffractometer (XRD, Rigaku Rint-2000) with $\mathrm{CuK} \alpha \mathrm{X}$ ray source $(40 \mathrm{kV}-40 \mathrm{~mA})$ and laser Raman spectroscopy 
(JASCO NRS-3100). A field emission scanning electron microscope (FESEM, JEOl-JSM7000F) and transmission electronic microscope (TEM, JEO1-JEM2000EX) were used for analyses of the morphology in the samples. Specific surface area was measured by nitrogen adsorption at $77 \mathrm{~K}$ on heated powder at $200^{\circ} \mathrm{C}$ using Shibata SA 1100 system.

Oxygen evolution from powders was examined by temperature-programmed reduction in $\mathrm{H}_{2}\left(\mathrm{H}_{2}-\mathrm{TPR}\right)^{16-18)}$. It was performed by using a lab-designed BP-1S (OkuraRiken Co.), which is equipped with a microreactor of quartz and a thermal conductivity detector (TCD) to monitor the composition change of gas. $5 \% \mathrm{H}_{2} / \mathrm{Ar}$ flowing gas was passed over $0.1 \mathrm{~g}$ powder at temperatures of $50-600^{\circ} \mathrm{C}$ with a constant heating rate. The change of gas composition was presented as TCD signals (the consumption of $\mathrm{H}_{2}$ due to $\mathrm{H}_{2}+\mathrm{O}$ (surface) $\rightarrow \mathrm{H}_{2} \mathrm{O}$ ) versus temperature. The heating rate was changed in a series of experiments from $5^{\circ} \mathrm{C} / \mathrm{min}$ to $20^{\circ} \mathrm{C} / \mathrm{min}$. The activation energy $\mathrm{E}$ and rate constant $\mathrm{k}$ for the reaction: $\mathrm{CeO}_{2}+\mathrm{xH}_{2}=\mathrm{CeO}_{2-\mathrm{x}}+\mathrm{xH}_{2} \mathrm{O}$ was measured by assumption of the first order reaction between $\mathrm{H}_{2}$ and $\mathrm{CeO}_{2}$. Here, $\mathrm{CeO}_{2}$ release oxygen on its surface and immediately the oxygen react with $\mathrm{H}_{2}$. The plot of $\ln (\mathrm{k})$ versus $1 / \mathrm{T}$ provides a straight line, where $\mathrm{k}$ is rate constant at the rate-maximum (peak in TPR curve) temperature, so that $E$ is simply obtained by the measurements with several different heating rates in reducing heat treatment of TPR experiments.

The oxygen absorption amount was measured after the reducing heat treatment of the powder at temperatures of $50-600^{\circ} \mathrm{C}$ with a heating rate of $10^{\circ} \mathrm{C} / \mathrm{min}$ and kept at $600{ }^{\circ} \mathrm{C}$ for $20 \mathrm{~min}$ in flowing $5 \% \mathrm{H}_{2} / \mathrm{Ar}$. The oxygen gas pulse was injected to the sample at $600{ }^{\circ} \mathrm{C}$ in flowing $\mathrm{He}$,

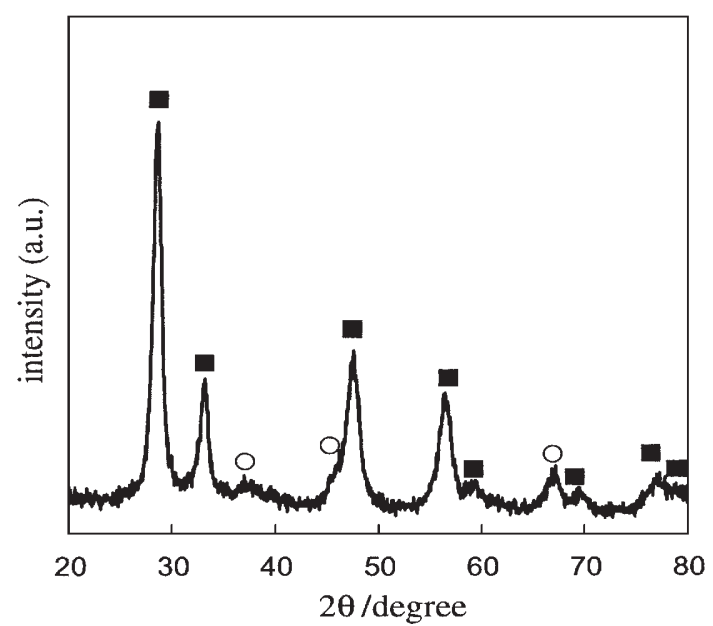

Fig. 1 XRD of a prepared powder after heat treatment at $600{ }^{\circ} \mathrm{C}$. : $\mathrm{CeO}_{2}, \mathrm{O}: \gamma-\mathrm{Al}_{2} \mathrm{O}_{3}$. and then total amount of oxygen absorbed was identified as the oxygen absorption amount. This is equal to total amount of oxygen storage capacity (OSC) of a powder in practice. In addition, the second TPR and $\mathrm{O}_{2}$ pules run was performed in the same apparatus without changing the sample set, temperature-gas schedule and apparatus just after cooled down in the first run.

\section{Result and discussion}

\subsection{Crystalline phase and microstructure}

The XRD indicated the mixture of two phases: $\mathrm{CeO}_{2}$ and $\gamma-\mathrm{Al}_{2} \mathrm{O}_{3}$ in a prepared powder after heat treatment at $600^{\circ} \mathrm{C}$, as shown in Fig. 1. The crystallite size of $\mathrm{CeO}_{2}$ was measured, using Hall's equation from XRD peak broadness versus diffraction angle, and was determined as $20 \mathrm{~nm}$ in diameter. Figure 2 shows the Raman spectra of commercial $\mathrm{CeO}_{2}$ powder and present $\mathrm{CeO}_{2} / \mathrm{Al}_{2} \mathrm{O}_{3}$ composite. Although the crystalline $\mathrm{CeO}_{2}$ itself shows only a single peak around $450 \mathrm{~cm}^{-1}$ (Fig. 2 (a)), additional scattering peaks at around 250 and $600 \mathrm{~cm}^{-1}$ was observed in present composite powder (Fig. 2(b)). These signals suggested the existence of the defects introduced in the $\mathrm{CeO}_{2}$ crystal lattice, which were characteristics for the dispersed $\mathrm{CeO}_{2}$ on $\mathrm{Al}_{2} \mathrm{O}_{3}$. The impregnation process followed by heat treatment might induce the diffusion of $\mathrm{Al}$ and $\mathrm{Ce}$ at interface as well as surface of powders, so that surface and interface defect of $\mathrm{CeO}_{2}$ is introduced by small amount of $\mathrm{Al}$ cation (trivalent) into $\mathrm{CeO}_{2}$. Other factor, which affects Raman spectra, is the large distortion of $\mathrm{CeO}_{2}$ lattice which is forced by surface of $\mathrm{Al}_{2} \mathrm{O}_{3}$. However, the new signal representing different symmetry $\left(250\right.$ and $\left.600 \mathrm{~cm}^{-1}\right)$ is more likely to defects by contacting or doping of $\mathrm{Al}_{2} \mathrm{O}_{3}$.

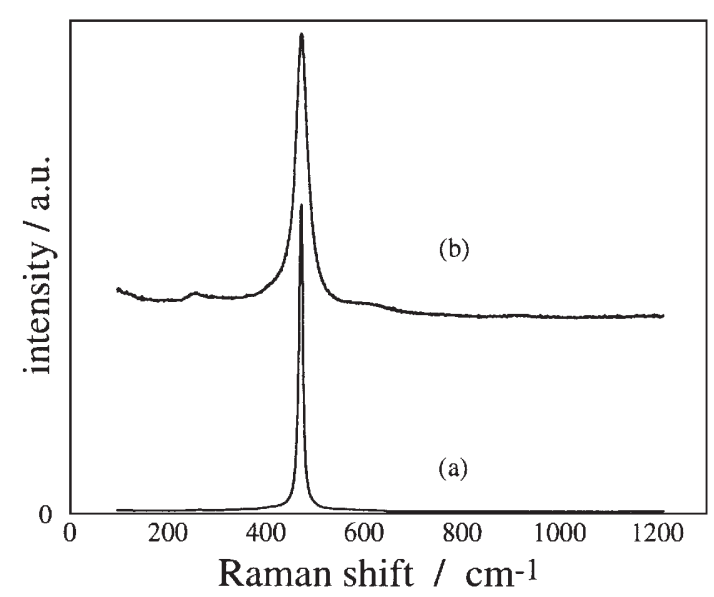

Fig. 2 Raman spectra of commercial $\mathrm{CeO}_{2}$ powder (a) and present $\mathrm{CeO}_{2} / \mathrm{Al}_{2} \mathrm{O}_{3}$ composite (b). 
Figure 3 shows the FESEM images, demonstrating the morphology and dispersion of $\mathrm{CeO}_{2}$ on $\mathrm{Al}_{2} \mathrm{O}_{3}$. The image (b) of Fig. 4 (REM image) shows the reflection electron intensity distribution, and the bright part indicates the area with the heavy metal composition of $\mathrm{CeO}_{2}$ in alumina matrix. The agglomeration sphere containing much of $\mathrm{CeO}_{2}$ is estimated as $100-500 \mathrm{~nm}$ in diameter. These $\mathrm{CeO}_{2}$ colonies are formed in the micropores of alumina where the crystalline $\mathrm{CeO}_{2}$ and $\mathrm{Al}_{2} \mathrm{O}_{3}$ particles become tight contact one another. The sphere-like colony will be induced by partially evaporated water in the mixture of aqueous $\mathrm{Ce}$ nitrate and $\mathrm{Al}_{2} \mathrm{O}_{3}$ powders during the drying process at $110^{\circ} \mathrm{C}$. This texture of present $\mathrm{CeO}_{2} / \mathrm{Al}_{2} \mathrm{O}_{3}$ is one of the characteristics by micrometer-scale observation of present composites.

Figure 4 shows the TEM observation of $\mathrm{CeO}_{2} / \mathrm{Al}_{2} \mathrm{O}_{3}$ composite powder. The image demonstrates that $\mathrm{CeO}_{2}$ is well contact with $\mathrm{Al}_{2} \mathrm{O}_{3}$ particles, and indicates the existence of partial coverage of nanometer-sized $\mathrm{CeO}_{2}$ along $\mathrm{Al}_{2} \mathrm{O}_{3}$ nanoparticles and $\mathrm{CeO}_{2}$ crystallites make lager interface area in $\mathrm{CeO}_{2} / \mathrm{Al}_{2} \mathrm{O}_{3}$ composite powder. The shape of $\mathrm{CeO}_{2}$ is likely thin layer along the surface of alumina particles. The crystallite size is in consistence with the size measured from XRD. This is also consistent to Raman spectrum, which indicates that $\mathrm{CeO}_{2}$ particles have defects and been distorted structure in the surface (Al-doping) and interface $\left(\mathrm{CeO}_{2} / \mathrm{Al}_{2} \mathrm{O}_{3}\right)$. Then the strong atomistic contact

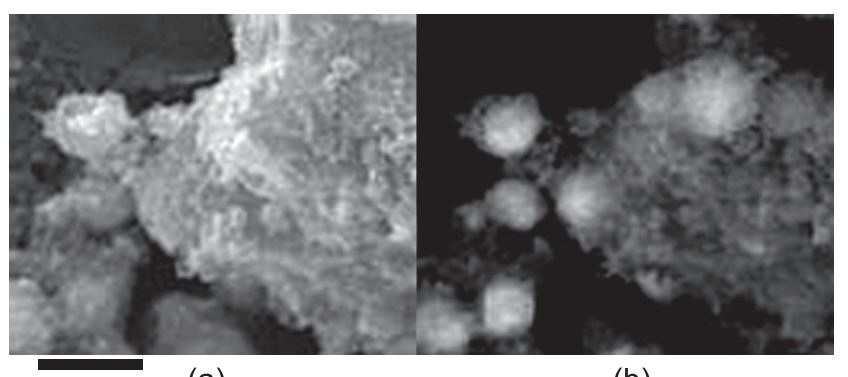

$500 \mathrm{~nm} \quad$ (a)

(b)

Fig. 3 FESEM image (a) and corresponding REM image (b).

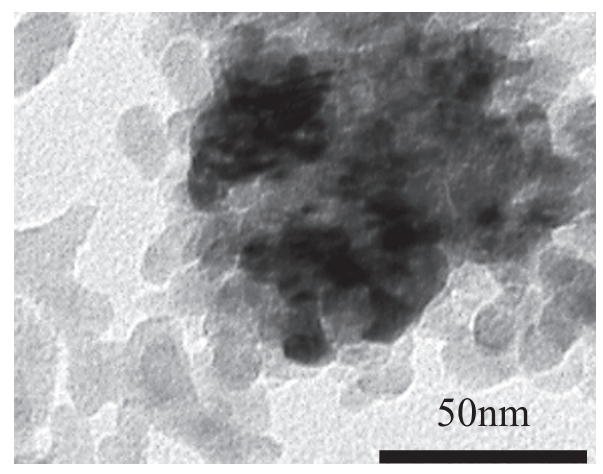

Fig. 4 TEM image of $\mathrm{CeO}_{2} / \mathrm{Al}_{2} \mathrm{O}_{3}$ composite powder. is expected for the composite of two kinds of nanoparticles with large interface area between $\mathrm{CeO}_{2}$ and $\mathrm{Al}_{2} \mathrm{O}_{3}$. The microstructural feature and surface coverage geometry of $\mathrm{CeO}_{2}$ with $\mathrm{Al}_{2} \mathrm{O}_{3}$ will be related to the activation of oxygen by the reaction with hydrogen. Also, the possible interface rearrangement of $\mathrm{CeO}_{2}$ with $\mathrm{Al}_{2} \mathrm{O}_{3}$ will be expected after heat treatment in reducing and oxidizing atmosphere. In next section, we determine the activation energy for hydrogen consumption by oxygen on $\mathrm{CeO}_{2} / \mathrm{Al}_{2} \mathrm{O}_{3}$.

3.2 Temperature programmed reduction and activation energy

Figure 5 shows the $\mathrm{H}_{2}$-TPR profiles of $\mathrm{CeO}_{2} / \mathrm{Al}_{2} \mathrm{O}_{3}$ at $40-600{ }^{\circ} \mathrm{C}$ at the $1 \mathrm{st}$ and $2 \mathrm{nd}$ runs in the repeated experiments. They show three peaks; the 1 st peak is desorption of water from powder surface, the 2 nd peak (peak A) is the hydrogen consumption at lower temperature, and the 3 rd peak (peak B) is the main peak for reaction between $\mathrm{H}_{2}$ and surface oxygen of $\mathrm{CeO}_{2}$. The peaks distributed at around $120-150^{\circ} \mathrm{C}, 420-450^{\circ} \mathrm{C}$ and $550-$ $580^{\circ} \mathrm{C}$, respectively. The peak of water desorption appeared in only the starting sample, but this peak does not appear at the 2 nd run. Yao et al. ${ }^{1)}$ have indicated the three TPR peaks at 500,750 and $850^{\circ} \mathrm{C}$ for $\mathrm{CeO}_{2} / \mathrm{Al}_{2} \mathrm{O}_{3}$ catalyst after pretreatment in $\mathrm{Ar}$, and suggested that the lowest-temperature peak corresponded to the surfacecapping, the 2nd for surface oxygen and the $3 \mathrm{rd}$ is bulk oxygen of $\mathrm{CeO}_{2}$. Duprez ${ }^{14)}$ has determined that the major oxygen which reacts with hydrogen is surface oxygen at the top layer of $\mathrm{CeO}_{2}$ using oxygen isotope method. Also, this result should be compared with $\mathrm{CeO}_{2} / \mathrm{Al}_{2} \mathrm{O}_{3}$ catalyst which was examined with TPR and XPS analysis by Shyu et al. ${ }^{19)}$. They assumed the formation of $\mathrm{CeAlO}_{3}$ on $\mathrm{Al}_{2} \mathrm{O}_{3}$ over a temperature of $800 \mathrm{~K}\left(527^{\circ} \mathrm{C}\right)$ in reduction condition,

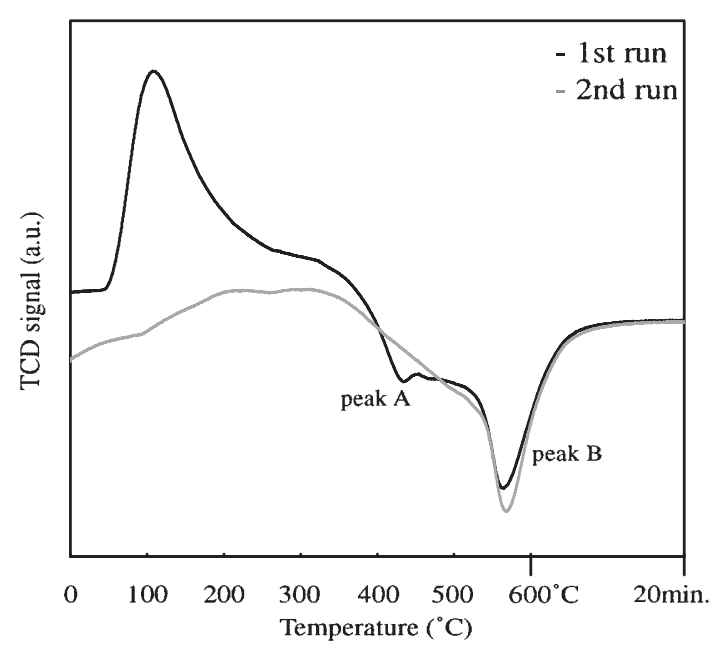

Fig. $5 \mathrm{H} 2-\mathrm{TPR}$ profiles of $\mathrm{CeO}_{2} / \mathrm{Al}_{2} \mathrm{O}_{3}$ at $40-600^{\circ} \mathrm{C}$ at the 1 st (black line) and 2nd runs (grey line). 
and discussed that a TPR peak in the temperature region around $400^{\circ} \mathrm{C}$ was attributed to surface oxygen on $\mathrm{CeAlO}_{3}$ although no repeated TPR data were indicated. In our data, the peak $\mathrm{A}$ was weakened by the reoxidizing treatment of powder at $600^{\circ} \mathrm{C}$ as shown a curve in the $2 n d$ TPR experiment. However, the broad trace around $400-450^{\circ} \mathrm{C}$ remained even in the 2 nd TPR profile, thus the oxygen adsorption function seems to remain as active sites of surface in low temperature region. The change of the 1 st and 2 nd TPR suggests that the surface structural rearrangement occurs during the cyclic redox heat treatment.

Table 1 summarizes the oxygen absorption and reaction parameters measured in this work. The activation energy $\mathrm{E}$ of $\mathrm{CeO}_{2} / \mathrm{Al}_{2} \mathrm{O}_{3}$ were determined to be $85 \pm 15 \mathrm{~kJ} / \mathrm{mol}$ for peak $A$, and $135 \pm 20 \mathrm{~kJ} / \mathrm{mol}$ for peak $B$ at the $1 \mathrm{st}$ TPR run. Since the peak A corresponds to capping oxygen after the elimination of water on surface, this oxygen should be more active than oxygen of $B$ and easily reacted with hydrogen at lower temperatures. Regarding the peak B, the oxygen species should be supplied by the surface layer in the crystal lattice of $\mathrm{CeO}_{2}$. This corresponds to that the $\mathrm{E}$ is required to be as large as $135 \pm 20 \mathrm{~kJ} / \mathrm{mol}$, which is associated with the diffusion or displacement of oxygen on surface of $\mathrm{CeO}_{2}$ in addition of decomposition of the $\mathrm{Ce}-\mathrm{O}$ bond and reaction to hydrogen. At the 2nd run of $\mathrm{CeO}_{2} / \mathrm{Al}_{2} \mathrm{O}_{3}$, the $\mathrm{E}$ for peak B was determined to be $194 \pm 25 \mathrm{~kJ} / \mathrm{mol}$. Thus, the reducing-oxidizing cyclic treatment induced larger activation energy in the reaction. It means the formation of the less active oxygen site, which is caused by the interface rearrangement during redox cycle and heat treatment in $\mathrm{CeO}_{2} / \mathrm{Al}_{2} \mathrm{O}_{3}$. Here, we should note that the change occurs at $600^{\circ} \mathrm{C}$ with no obvious change of bulk solid state which could be observed by XRD and Raman spectra. Since the same $\mathrm{Al}_{2} \mathrm{O}_{3} / \mathrm{CeO}_{2}$ shows the solid state reaction between $\mathrm{CeO}_{2}$ and $\mathrm{Al}_{2} \mathrm{O}_{3}$ by heat treatment in the reducing atmosphere $\left(5 \% \mathrm{H}_{2} / \mathrm{Ar}\right)$ at $900{ }^{\circ} \mathrm{C}$, there is large possibility of structural change due to lattice relaxation by the formation of trivalent $\mathrm{Ce}$ at their interface in lower temperature region than $900^{\circ} \mathrm{C}$. So in this work we can suggest the atomistic interaction of $\mathrm{Al}-\mathrm{O}-\mathrm{Ce}$ at the interface in $\mathrm{CeO}_{2} / \mathrm{Al}_{2} \mathrm{O}_{3}$ composite at lower temperature region.

3.3 Oxygen absorption property
The oxygen absorption at $600^{\circ} \mathrm{C}$ was measured as 2.03 $\pm 0.06 \mathrm{ml} / \mathrm{g}$ after the $1 \mathrm{st}$ reducing heat treatment at $600^{\circ} \mathrm{C}$ in flowing $5 \% \mathrm{H}_{2} / \mathrm{Ar}$ gas. It increased to $2.17 \pm 0.06 \mathrm{ml} / \mathrm{g}$ after the 2 nd run, and after 3 rd run this value was the same. It is newly found the slight improvement in oxygen absorption, which means oxygen storage capacity in catalyst, after the reduction-oxidation treatment at $600^{\circ} \mathrm{C}$. This is probably due to the additional active oxygen site which is produced in the interface layer of $\mathrm{CeO}_{2}$ with $\mathrm{Al}_{2} \mathrm{O}_{3}$.

The oxygen evolution of pure $\mathrm{CeO}_{2}$ is related to oxygen only in a surface layer but not to the lattice oxygen inside crystal lattice ${ }^{3)}$. Therefore, the structural change at the interface between $\mathrm{CeO}_{2}$ and $\mathrm{Al}_{2} \mathrm{O}_{3}$ is strongly suggested, regarding the increase of oxygen absorption. Since there was no obvious microstructural change in the bulk state elucidated by XRD and Raman analyses, the interaction is limited in atomistic bond relaxation in the interface of two crystalline oxides. The activation energy of oxygen evolution after redox treatment was increased by redox treatment of $\mathrm{CeO}_{2} / \mathrm{Al}_{2} \mathrm{O}_{3}$ composite powder, although the amount of released oxygen increased. This also means that the structural modification and stabilized oxygen site should be induced by relaxing bond strength (and length) between oxygen and cations ( $\mathrm{Ce}$ and $\mathrm{Al})$ at the interface. Thus, the oxygen is locally stabilized to make relaxed structure in interface region, and then the high activation energy of oxygen evolution is due to the modification of structure after redox treatment. Also, the relaxed structure slightly increases to form more sites of oxygen releasing and absorbing properties. It is expected that the addition of $\mathrm{Al}_{2} \mathrm{O}_{3}$ on $\mathrm{CeO}_{2}$ catalyst is effective if the interface oxygen is evolved with the reaction such as oxygen storage capacity. New oxygen releasing and absorbing property at interface of $\mathrm{CeO}_{2} / \mathrm{Al}_{2} \mathrm{O}_{3}$ after redox treatment is suggested by the TPR experiments and speculated by the initial microstructure in $\mathrm{CeO}_{2} / \mathrm{Al}_{2} \mathrm{O}_{3}$ with nanometer-scale. This work has found a novel mechanism of OSC at interface of $\mathrm{CeO}_{2} / \mathrm{Al}_{2} \mathrm{O}_{3}$ at low temperature region below $600^{\circ} \mathrm{C}$.

\section{Conclusion}

Oxygen release property of ceria $\left(\mathrm{CeO}_{2}\right)$ at interface

Table 1 Surface area, crystallite size, OSC, and TPR characters for $30 \mathrm{~mol} \% \mathrm{CeO}_{2} / \mathrm{Al}_{2} \mathrm{O}_{3}$.

\begin{tabular}{ccccccc}
\hline $\begin{array}{c}\text { Surface area } \\
\left(\mathrm{m}^{2} / \mathrm{g}\right)\end{array}$ & $\begin{array}{c}\text { Size D } \\
(\mathrm{nm})\end{array}$ & $\begin{array}{l}\text { 1st TPR } \\
\text { OSC }(\mathrm{ml} / \mathrm{g})\end{array}$ & $\begin{array}{l}\text { 1st TPR Activation Energy } \\
\mathbf{E}_{\mathrm{A}}(\mathrm{kJ} / \mathrm{mol})\end{array}$ & $\begin{array}{l}\text { 2nd TPR } \\
\text { OSJ }(\mathrm{kJ} / \mathrm{mol})\end{array}$ & $\begin{array}{l}\text { 2st TPR Activation Energy } \\
\mathbf{E}_{\mathrm{B}}(\mathrm{kJ} / \mathrm{mol})\end{array}$ \\
\hline 71.7 & 29 & $2.03 \pm 0.06$ & $85 \pm 15$ & $135 \pm 20$ & $2.17 \pm 0.06$ & $194 \pm 25$ \\
\hline
\end{tabular}


between alumina and ceria by hydrogen was examined by the temperature-programmed reduction technique below the temperature of $600^{\circ} \mathrm{C}$. We found a slight improvement of oxygen absorption amount in the reduction and oxidation condition at $600^{\circ} \mathrm{C}$. The activation energy $\mathrm{E}$ was $135 \pm 20$ $\mathrm{kJ} / \mathrm{mol}$ and $194 \pm 25 \mathrm{~kJ} / \mathrm{mol}$ before and after redox treatment, respectively, for a major oxygen release peak of $\mathrm{CeO}_{2} / \mathrm{Al}_{2} \mathrm{O}_{3}$. The strong interaction at the interface between $\mathrm{CeO}_{2}$ and $\mathrm{Al}_{2} \mathrm{O}_{3}$ was observed under redox condition even at as low temperatures as $600{ }^{\circ} \mathrm{C}$. The oxygen is locally stabilized in the relaxed structure of interface region in which oxygen is also stabilized. The high activation energy of oxygen evolution is due to the modification of structure after redox treatment.

A part of this paper was presented at 2010 fall meetings (3-9B) and 2011 spring meetings (1-52B) of Power and Power metallurgy Society of Japan. Work was partially supported by a project of the New Energy and Industrial Technology Development Organization (NEDO): "Rare Metal Substitute Materials Development Project".

\section{References}

1) H.C. Yao, Y.F. Yu-Yao: "Ceria in Automotive Exhaust Catalysts", Journal of Catalysis, 86(1984)254-265.

2) Y.Zhou, M.N. Rahaman: "Effect of redox reaction on the sintering behavior of cerium oxide", Acta Materia, 45(1997)3635-3639.

3) A. Trovarelli: "Catalytic Properties of Ceria and $\mathrm{CeO}_{2}$ Containing Materials", Catalysis Review, 38(1996) 439-520.

4) M. Sugiura, M. Ozawa, A. Suda, T. Suzuki, T. Kanazawa: "Development of Innovative Three-Way Catalysts Containing Ceria-Zirconia Solid Solutions with High Oxygen Storage/Release Capacity", Bulletin of Chemical Society of Japan, 78(2005)752-759

5) G. Adachi: "Science of rare earth", Kgaku-Doujin, (1999) 848-849.

6) M. Ozawa, C.-K. Loong: "In situ X-ray and neutron powder diffraction studies of redox behavior in $\mathrm{CeO}_{2}$ containing oxide catalysts", Catalysis Today, 50(1999) 329-342.

7) M. Ozawa, M. Kimura, A. Isogai: "Application of $\mathrm{Ce}-\mathrm{Zr}$ oxide solid solution to automotive three way catalyst", Journal of Alloys and Compounds, 193
(1993) 72-75.

8) M. Ozawa: "Role of cerium-zirconium mixed oxides as catalysts for car pollution: A short review", Journal of Alloys and Compounds, 275-277(1998) 886-890.

9) M. Ozawa, M. Kimura: "Thermal Stability of Ce Added $\gamma-\mathrm{Al}_{2} \mathrm{O}_{3}$ ", J. Jpn. Soc. Powder Powder Metallurgy, 37 (1990)466-473.

10) M. Ozawa, M. Kimura, A. Isogai: "Thermal stability and characterization of gamma alumina modified with rare earths", Journal of Less-common Metals, 162 (1990)297-308.

11) A. Piras, A. Trovarelli, G. Dolcetti: "Remarkable stabilization of transition alumina operated by ceria under reducing and redox conditions", Applied Catalysis, B Environmental, 28(2000)L77-L81.

12) M. Haneda, T. Mizushima, N. Kakuta, A. Ueno, Y. Sato, S. Matsuura, K. Kasahara, M. Sato: "Structural Characterization and Catalytic Behavior of $\mathrm{Al}_{2} \mathrm{O}_{3^{-}}$ Supported Cerium Oxides", Bulletin of Chemical Society of Japan, 66(1993)1279-1288.

13) H. Imagawa, A. Suda, K. Yamamura, S. Sun: "Monodisperse $\mathrm{CeO}_{2}$ Nanoparticles and Their Oxygen Storage and Release Properties", Journal of Physical Chemistry C, 115(2011)1740-1745.

14) D. Duprez: "Study of surface reaction mechanisms by ${ }^{16} \mathrm{O} /{ }^{18} \mathrm{O}$ and $\mathrm{H} / \mathrm{D}$ isotopic exchange", Catalysis Today, 112(2006) 17-22.

15) M. Ozawa, M. Hattori, T. Yamaguchi: "Thermal stability of ceria catalyst on alumina and its surface oxygen storage capacity", Journal of Alloys and Compounds, 451(2008)621-623.

16) V.P. Zhdanov, B. Kasemo: "Kinetic models of oxygen supply from $\mathrm{CeOx}$ to active nanometer particles", Applied Surface Science, 135(1998)297-3066.

17) F. Giordano, A. Trovarelli, C. Leitenburg, M. Giona: "A Model for the Temperature-Programmed Reduction of Low and High Surface Area Ceria", Journal of Catalyst, 193(2000)273-282.

18) H.A. Al-Madfaa, M.M. Khader: "Reduction kinetics of ceria surface by hydrogen", Materials Chemistry and Physics, 86(2004)180-188.

19) J.Z. Shyu, W.H. Weber, H.S. Gandhi: "Surface characterization of alumina-supported ceria", J. Phys. Chem., 92(1988)4964-4970. 